\title{
RELASI ANTARA SUPERVISI DENGAN KINERJA PELAKSANAAN ASUHAN KEPERAWATAN DALAM MEMAKSIMALKAN PROSES KEPERAWATAN
}

\author{
Nikita Gina Chesena Sembiring \\ nikitagina.ng@gmail.com
}

\section{LATAR BELAKANG}

Berlakunya sistem jaminan kesehatan telah membuka akses pelayanan kesehatan bagi seluruh masyarakat Indonesia untuk mendapat pelayanan kesehatan yang bermutu. Dalam Undang-Undang Nomor 40 tahun 2004 bahwa setiap masyarakat Indonesia memiliki hak untuk mendapat pelayanan kesehatan. Undang-undang No. 44 Tahun 2009 pasal 32d menyatakan setiap pasien memiliki hak untuk memperoleh layanan kesehatan yang bermutu sesuai dengan standar profesi dan standar prosedur operasional.

Berdasarkan Undang-undang No.44 Tahun 2009 tentang rumah sakit, rumah sakit merupakan institusi pelayanan kesehatan yang menyelenggarakan pelayanan kesehatan perorangan secara paripurna yang menyediakan pelayanan rawat inap, rawat jalan dan gawat darurat.Menurut WHO rumah sakit adalah integral dari suatu organisasi social dan kesehatan dengan fungsi menyediakan pelayanan paripurna (komprehensif), penyembuhan penyakit (kuratif) dan pencegahan penyakit (preventif) kepada masyarakat.

Perawat adalah individu yang mempunyai profesi berdasarkan pengetahuan ilmiah, keterampilan serta sikap kerja yang dilandasi oleh rasa tanggung jawab dan pengabdian kepada klien dalam bentuk pelayanan professional yang bertujuan membantu pasien untuk memulihkan dan meningkatkan kemampuan dirinya. Pelayanan keperawatan di ruang rawat terdiri atas serangkaian kegiatan yang dikoordinasi oleh kepala ruang rawat dan menjadi tanggung jawab sebagai manajer (Simamora, R. 2012).

Untuk meningkatkan serta dapat memepertahankan mutu dari pelayanan, maka perlu memperhatikan kualitas pelayanan keperawatan.Pelayanan keperawatan adalah pelayanan profesional sebagai bagian integral dari pelayanan kesehatan yang didasarkan pada ilmu dan kiat 
keperawatan (Nursalam,2008). Keperawatan adalah salah satu profesi pemberi pelayanan kesehatan, yang memiliki peran penting dalam menentukan keberhasilan kesehatan secara keseluruhan. Calista Roy (1976) mengartikan keperawatan adalah praktik keperawatan yang memiliki sekumpulan pengetahuan untuk memberi pelayanan kesehatan pada pasien. Maka keperawatan adalah upaya pemberian asuhan yang bersifat humanistik dan professional, holistic berdasarkan ilmu dan kiat, standart pelayanan dengan berpegang teguh pada kode etik yang mendasari perawat profesional secara mandiri atau dengan upaya kolaborasi.

Kinerja adalah seperangkat hasil yang dicapai untuk merujuk pada tindakan pencapaian serta pelaksanaan sesuatu pekerjaan yang diminta.

Kinerja yang baik dapat memberi dampak terhadap peningkatan mutu pelayanan klinis dalam tim, kinerja perawat juga dapat digunakan untuk mewujudkan komitmen pegawai dalam kontribusinya secara profesional guna meningkatkan mutu pelayanan sehingga kualitas hidup dan kesejahteraan masyarakat makin meningkat (Mangkunegara, 2006).

Produktivitas dalam keperawatan dihubungkan dengan efisiensi dan keefektifan perawat dalam memberikan asuhan keperawatan. Kepala ruangan dapat meningkatkan produktivitas perawat pelaksana dengan memberikan motivasi (Swanburg,2010).

Supervisi keperawatan merupakan suatu bentuk kegiatan manajemen keperawatan yang bertujuan dalam pemenuhan dan peningkatan pelayanan untuk klien dan keluarga yang berfokus pada kebutuhan, keterampilan dan kemampuan perawat dalam melaksanakan tugas (Nursalam,2015)

Dalam melakukan tindakan keperawatan, banyak unsur yang berperan serta mendukung fungsi pelayanan prima jasa kesehatan. Pada pelayanan keperawatan manajemen asuhan keperawatan sangat diperlukan.Asuhan keperawatan adalah proses atau rangkaian kegiatan pada praktik keperawatan yang diberi secara langsung pada pasien di berbagai tatanan layanan kesehatan. Dalam memberi asuhan keperawatan, perawat menggunakan proses keperawatan dengan lima tahapan, karena dengan proses keperawatan asuhan dapat menjadi komprehensif (Hariyati,2014).Proses manajemen dimulai dari perencanaan, pengorganisasian, ketenagaan, pengarahan, dan pengendalian, terhadap factor sumber daya manusia, keuangan, material, metode, dan fasilitas (Marquis \& Huston, 2015). Asuhan keperawatan dapat 
dipertanggungjawabkan berdasarkan substansi ilmiah yaitu logis, sistematis, dinamis dan restruktur (Muhlisin,2011).

Proses keperawatan adalah metode sistematis untuk menilai, mendiagnosis, merencanakan, melaksankan, dan mengevaluasi keadaan pasien dalam keadaan sehat maupun sakit sehingga menjadi dasar pemecahan secara ilmiah, dan menjadi dasar dalam praktik keperawatan (Baraki et al., 2017).Proses keperawatan adalah kegiatan praktik keperawatan yang dilakukan dengan cara yang sistematik. Selama melakukan proses keperawatan, perawat menggunakan dasar atau landasan pengetahuan yang komprehensif untuk mengakaji status kesehatan pasien, membuat penilaian yang bijaksana dan mendiagnosa, mengidentifikasi hasil akhir kesehatan pasien, dan merencanakan, menerapkan serta mengevaluasi tindakan keperawatan yang tepat, untuk mencapai hasil akhir tersebut (Dermawan, 2012).

\section{METODE}

Kajian ini dilakukan dengan metode menganalisis dari berbagai sumber bacaan. Baik dari berbagai jurnal online, buku ataupun e-book, yang memiliki hubungan dengan asuhan keperawatan dan proses keperawatan.

Penulisan kajian ini melakukan metode perbandingan antar satu artikel dengan artikel lainnya. Kemudian perbandingannya ditulis secara beraturan dalam hasil dari kajian. Dengan isi yang akan dibadingkan tetap berhubungan dengan asuhan keperawatan dan proses keperawatan.

\section{HASIL}

Hasil dari literature review didapat bahwa pemanfaatan konsep dasar proses keperawatan sangat bermanfaat bagi tenaga kesehatan, khususnya bagi perawat untuk menciptakan asuhan keperawatan yang maksimal serta berkualitas. Adapun jurnal yang terkait adalah :

\section{Jurnal Manajemen Model Asuhan Keperawatan Professional (MAKP) Tim Dalam} Peningkatan Kepuasan Pasien di Rumah Sakit (Nur Hidayah,2014).Hasil penelitian jurnal ini dapat disimpulkan, bentuk pelayanan keperawatan dalam rangka meningkatkan kualitas pelayanan adalah dengan memberikan rasa tanggung jawab perawat yang tinggi agar terjadi peningkatan kinerja kerja dan kepusan pasien. Jenis model asuhan keperawatan professional : MAKP Fungsional, MAKP Kasus, MAKP Primer, MAKP Tim. Manajemen asuhan keperawatan 
pada proses keperawatan yaitu : pengkajian, diagnosis keperawatan, intervensi, implementasi, evaluasi. Dalam pelaksanaan model asuhan keperawatan professional tim kegiatan yang mutlak dan harus dilakukan dan diterapkan dengan baik di rumah sakit, yaitu supervise, timbang terima, sentralisasi obat dan dokumentasi keperawatan yang baik, jika dapat dilakukan dengan benar dan baik maka semakin baik pelaksanaan MAKP Tim dan tentunya akan meningkatkan mutu pelayanan kesehatan serta meningkatkan kepuasaan pasien di rumah sakit.

\section{Jurnal Hubungan Karakteristik Perawat, Motivasi, dan Supervisi Dengan Kualitas}

\section{Dokumentasi Proses Asuhan Keperawatan (Retyaningsih Ida Yanti, Bambang Edi}

Warsito.,2013). Metode penelitian jurnal ini dengan penelitian kuantitatif dengan desain penelitian potong lintang dan bersifat deskriptif korelatif. Dari jurnal tersebut dapat disimpulkan : pertama bahwa karakteristik perawat yang dapat dilihat dari segi umur, jenis kelamin, tingkat pedidikan, masa kerja, dan pelatihan. Yang kemudian masing-masing dihubungkan dengan kualitas dokumentasi proses asuhan keperawatan, dan didapat hasil uji statistic bahwa masing-masing segi tersebut tidak ada hubungannya dengan kualitas dokumentasi proses asuhan keperawatan. Kedua, motivasi kerja yang tinggi menjadikan perawat mempunyai semangat kerja yang tinggi untuk memberikan pelayanan yang terbaik. Maka motivasi dengan kualtitas dokumentasi proses asuhan keperawatan memiliki hubungan. Ketiga, supervise yang dilakukan dengan benar merupakan bentuk dukungan dari lingkungan untuk meningkatkan kualtitas kerja perawat sehingga kualitas dokumen proses asuhan keperawatan yang baik pula. Maka supervise dengan kualitas dokumentasi proses asuhan keperawatan memiliki hubungan.

\section{Jurnal Hubungan Fungsi Supervisi Kepala Ruangan Dengan Produktivitas Kerja} Perawat Pelaksana di Rumah Sakit Umum Daerah dr. Pirngadi Medan (Havija Sihotang, Heru Santosa, Salbiah., 2016) metode penelitian pada jurnal ini dengan deskriptif korelasi dengan desain cross sectional yang bertujuan untuk mengetahui hubungan fungsi supervise kepala ruangan dengan produktivitas kerja perawat pelaksana di Rumah Sakit Umum Daerah Dr. Pirngadi Medan. Kesimpulan yang didapat adalah : berdasarkan hasil korelasi diketahui bahwa fungsi supervise kepala ruangan telah dilaksanakan dnegan baik. Produktivitas kerja perawat pelaksana juga diketahui mendekati nilai maksimal. Penelitian ini menunjukkan bahwa apabila fungsi supervise dilaksanakan dengan baik maka produktivitas kerja perawat pelaksana juga akan baik. 


\section{Jurnal Hubungan Supervisi Keperawatan dengan Perilaku Caring Perawat dalam}

Merawat Pasien Kritis (Rohmatulloh, Ani Haryani., 2018). Metode penelitian jurnal ini adalah analitik korelasi dengan menggunakan pendekatan cross sectional yang dilakukan di Rumah Sakit dr. Drajat Prawiranegara (RSDP) Serang. Kesimpulan yang didapat adalah bahwa semakin sering supervise keperawatan dilakukan maka semakin baik perilaku caring perawat. Supervise keperawatan yang baik tentu akan berdampak pada pelayanan keperawatan yang baik. Hasil penelitian ini menunjukkan bahwa terdapat hubungan yang signifikan antara supervise keperawatan yang dilakukan oleh kepala ruangan atau pengawas keperawatan terhadap perilaku caring perawat dalam merawat pasien kritis.

Jurnal Pengaruh Supervisi Kepala Ruangan Terhadap Pelaksanaan Pendokumentasian Asuhan Keperawatan di Ruang Rawat Inap RSU Aisyiyah Padang Tahun 2018 (Asmawati, Yuanita Ananda, Alkafi., 2018). Metode penelitian dari jurnal ini adalah penelitian preeksperimental design dengan rancangan One Group pretest-postest Design. Dilakukan pada Mei sampai Agustus 2018 di RSU Aisyiah Padang. Kesimpulan dari jurnal ini adalah bahwa supervise dapat meningkatkan pelaksanaan pendokumentasian asuhan keperawatan.

Jurnal hubungan pelaksanaan supervisi kepala ruang dengan pendokumentasian asuhan keperawatan di Rumah Sakit Martha Friska Pulo Brayan(Magdalena Ginting Junita romaito Sinaga, 2019).Jurnal ini menggunakan metode penelitian deskriptif korelasi yang bertujuan untuk menganalisis hubungan supervisi kepala ruangan dengan pendokumentasian asuhan keperawatan. Kesimpulan yang didapat dari jurnal ini adalah bahwa penelitian mengasumsikan bahwa supervisi kepala ruangan yang baik tentang kelengkapan dokumentasi asuhan keperawatan akan berakibat pada penulisan dokumentasi yang lengkap oleh perawat pelaksana.

Jurnal analisis pelaksanaan fungsi manajemen pengarahan kepala ruangan dengan kinerja perawat dalam menerapkan asuhan keperawatan di ruang rawat inap RSUD Bima (Zulkarnain, 2017). Metode penelitian jurnal ini adalah studi kuantitatif dengan rancangan deskriptif dengan pendekatan cross sectional penelitian dilakukan pada perawat pelaksana yang bekerja di ruang rawat inap. Kesimpulan dari hasil penelitian ini adalah bahwa Terdapat hubungan pelaksanaan fungsi pengarahan kepala ruangan dengan kinerja perawat dalam menerapkan asuhan keperawatan di ruang rawat inap RSUD Bima dengan hasil analisis nilai. Terdapat hubungan yang bermakna, antara sub variabel fungsi pengarahan yang terdiri dari 
motivasi, komunikasi, supervisi, delegasi dan manajemen konflik, yang memiliki hubungan dengan kinerja perawat dalam menerapkan asuhan keperawatan di ruang rawat inap RSUD Bima.

\section{PEMBAHASAN}

Keperawatan adalah bentuk pelayanan professional yang menjadi bagian integral dari pelayanan kesehatan, didasarkan pada ilmu dan kiat keperawatan. Pelayanan yang diberikan berbentuk pelayanan bio-psiko-sosial-spiritual yang komprehensif, ditujukan kepada individu, keluarga dan masyarakat, baik sehat maupun sakit yang mencakup seluruh proses kehidupan manusia. Dalam hal ini, keperawatan termasuk kedalam organisasi pelayanan kesehatan, yang tentunya terlibat dalam penerapan manajemen dan pencapaian tujuan keperawatan (Simamora,R. 2012).

\section{SUPERVISI}

\section{DEFINISI SUPERVISI}

Supervisi merupakan bagian dari fungsi pengarahan yang berperan untuk mempertahankan segala kegiatan yang telah terprogram agar bisa dilaksankan dengan baik dan lancer. Dalam pelaksanaan asuhan keperawatan diperlukan pengarahan dan pengawasan melalui kegiatan supervisi. Supervisi adalah suatu proses kemudahan untuk penyelesaian tugas-tugas keperawatan (Swanburg \& Swansburg,1999). Kegiatan supervisi adalah kegiatan yang terencana seorang menejer melalui aktivitas bimbingan, pengarahan, observasi, motivasi, dan evaluasi pada stafnya dalam melaksanakan kegiatan atau tugas sehari-hari (Arwani,2006). Menurut Deming dalam Robbins (2010) menyatakan bahwa manajer bukan pekerja, manajer berperan melakukan supervise sebagai sumber utama peningkatan produktifitas. Supervisi merupakan salah satu standar dari praktik professional dalam organisasi. Supervisi adalah suatu strategi tata kelola kualitas maupun kompetensi yang bertujuan untuk meningkatkan kualitas pelayanan keperawatan (Dawson, Phillips, dan Leggat, 2012).

Kegiatan supervisi merupakan dorongan bimbingan dan kesempatan bagi pertumbuhan dan perkembangan keahlian dan kecakapan para perawat (Suyanto, 2009). Supervisi keperawatan adalah kegiatan pengawasan dan pembinaan yang dilakukan secara 
berkesinambungan oleh supervisor mencakup masalah pelayanan keperawatan, masalah ketenagaan dan peralatan, agar pasien mendapat pelayanan bermutu setiap saat (Depkes,2000 dalam Nursalam, 2012).

\section{MANFAAT DAN TUJUAN SUPERVISI}

Manfaat dan tujuan supervise adalah (Azwar,2010; Suarli \& Bahtiar 2009) :

a. Supervisi dapat meningkatkan efektifitas kerja. Peningkatan efektifitas kerja ini berhubungan erat dengan peningkatan pengetahuan dan keterampilan bawahan, serta semakin terbina hubungan dan suasana kerja yang lebih harmonis antara atasan dan bawahan.

b. Supervisi dapat meningkatkan efesiensi kerja. Yang berhubungan erat dengan makin berkurangnya kesalahan yang dilakukan bawahan, sehingga pemakaian sumber daya (tenaga, harta dan sarana) yang sia-sia akan dapat dicegah.

Apabila kedua peningkatan ini dapat terwujud, sama artinya dengan telah tercapainya tujuan dari suatu organisasi.

Tujuan pokok supervisi adalah menjamin pelaksanaan berbagai kegiatan yang telah direncanakan secara benar dan tepat, dalam arti lebih efektif dan efisien, sehingga tujuan yang telah ditetapkan organisasi dapat tercapai dengan capaian yang memuaskan (Suarli \& Bachtiar,2008).

\section{FREKUENSI PELAKSANAAN SUPERVISI}

Supervisi harus dilakukan dengan frekuensi yang berkala. Supervisi yang dilakukan hanya sekali dapat dikatakan bukan supervise yang baik. Karena organisasi atau lingkungan selalu berkembang (Suarli Bachtiar, 2009).

Supervisi memang belum optimal, seperti frekuensi pelaksanaannya yang tidak teratur. Tidak ada pedoman yang pasti mengatakan berapa kali supervisi harus dilakukan. Hal yang digunakan sebagai pegangan umum, supervisi biasanya bergantung dari derajat kesulitan pekerjaan yang dilakukan, serta sifat penyesuaian yang akan dilakukan. Jika derajat kesulitan 
tinggi serta sifat penyesuaiannya mendasar, maka supervisi harus lebih sering dilakukan (Azwar,2010; Suarli Bachtiar, 2009).

\section{PRINSIP POKOK DALAM SUPERVISI}

(Suarli \& Bachtiar,2009) :

a. Tujuan utamanya yaitu lebih meningkatkan kinerja bawahan, bukan untuk mencari kesalahan.

b. Sifat supervisi harus edukatif dan suportif, bukan otoriter. Supervise harus dilakukan secara berkala.

c. Supervisi harus dilaksanakan sedemikian rupa sehingga terjalin kerja sama yang baik antara atasan dengan bawahan.

d. Strategi dan tata cara supervisi yang akan dilakukan harus sesuai dengan kebutuhan masing-masing bawahan secara individu.

e. Supervisi harus dilaksanakan dengan fleksibel dan disesuaikan dengan perkembangan.

\section{PELAKSANA SUPERVISI}

Supervisi keperawatan dilaksanakan oleh personil atau bagian yang bertanggung jawab (Suyanto, 2009; Suarli \& Bachtiar, 2009) yaitu :

a. Kepala ruangan, kepala ruangan mengawasi perawat pelaksana dalam memberikan asuhan keperawatan baik secara langsung atau tidak langsung yang disesuaikan dengan metode penugasan yang diterapkan di ruang perawatan tersebut.

b. Pengawas perawatan (supervisor), bertanggung jawab mengawasi jalannya pelayanan keperawatan.

c. Kepala bidang perawatan, sebagai top manajer keperawatan yang bertanggung jawab melakukan supervisi baik langsung atau tidak melalui para pengawas keperawatan.

Kegiatan pokok pada dasarnya supervisi mencakup empat hal yaitu :

1) Menetapkan masalah dan prioritas

2) Menetapkan penyebab masalah, prioritas dan jalan keluar 
3) Melaksanakan jalan keluar

4) Menilai hasil yang dicapai untuk tindak lanjut berikutnya.

Pelaksanaan supervisi yang baik dilakukan dengan dua teknik, dimana dilakukan secara langsung atau tidak langsung (Nursalam,2015).

1. Teknik supervisi secara pengamatan langsung, ada beberapa hal yang harus diperhatikan yaitu sasaran pengamatan, objektivitas pengamatan, dan pendekatan pengamatan.

2. Secara tidak langsung, melalui laporan baik tertulis maupun lisan, supervisor tidak melakukan pengamatan langsung di lapangan seperti teknik supervisi secara langsung, sehingga mungkin terjadi kesenjangan fakta, umpan balik dapat diberikan secara tertulis.

\section{KOMPETENSI SUPERVISOR KEPERAWATAN}

Menurut Suyanto (2009), seorang supervisor keperawatan dalam menjalankan tugasnya seharihari harus memiliki kemampuan dalam :

a. Memberi pengarahan dan petunjuk yang jelas, sehingga dapat dimengerti oleh staf dan pelaksana keperawatan.

b. Memberikan saran, nasihat dan bantuan kepada staf dan pelaksana keperawatan

c. Memberi motivasi untuk meningkatkan semangat kerja kepada staf dan pelaksana keperawatan

d. Mampu memahami suatu proses kelompok (dinamika kelompok)

e. Memberi latihan dan bimbingan yang dibutuhkan oleh staf dan pelaksana keperawatan

f. Melakukan penilaian terhadap penampilan kinerja perawat, dan

g. Mengadakan pengawasan agar asuhan keperawatan yang diberikan lebih baik.

\section{MODEL SUPERVISI KEPERAWATAN}

Suyanto 2009, beberapa model supervisi dapat diterapkan dalam kegiatan supervisi : 
a. Model konvensional, dilakukan melalui inspeksi langsung untuk menemukan masalah dan kesalahan dalam pemberian asuhan keperawatan. Model ini sering tidak adil, karena hanya melihat sisi negatif dari pelaksanaan pekerjaan yang dilakukan perawat pelaksana sehingga sulit terungkap sisi positif, hal yang baik atau keberhasilan yang telah dilakukan.

b. Model ilmiah, dilakukan dengan pendekatan yang sudah direncanakan sehingga tidak hanya mencari kesalahan atau masalah saja. Model ini memiliki karakteristik yaitu : dilakukan secara berkesinambungan, dengan prosedur, instrument dan standar supervisi yang baku, menggunakan data yang objektif sehingga memberikan umpan balik dan bimbingan.

c. Model klinis, bertujuan membantu perawat pelaksana dalam mengembangkan profesionalisme sehingga penampilan dan kinerjanya dalam memberi asuhan keperawatan meningkat. Model ini dilakukan secara sistematis melalui pengamatan pelayanan keperawatan yang diberikan oleh seorang perawat selanjutnya dibanding dengan standar keperawatan.

d. Model artisik dilakukan dengan pendekatan personal untuk menciptakan rasa aman sehingga supervisor dapat diterima oleh perawat pelaksana yang disupervisi. Sehingga tercipta hubungan saling percaya.

\section{ASUHAN KEPERAWATAN}

\section{DEFINISI ASUHAN KEPERAWATAN}

Asuhan keperawatan adalah proses atau rangkaian kegiatan praktik keperawatan langsung pada klien di berbagai tatanan pelayanan kesehatan. Proses asuhan keperawatan merupakan tugas dan kewajiban seoramg perawat dari pasien dating sampai pasien pulang, dimulai dengan pengkajian secara menyeluruh, kemudian menegakkan diagnosa keperawatan dari data pengkajian tersebut, serta melakukan intervensi, implementasi dan evaluasi keefektifan diagnose awal yang sudah ditegakkan (Nursalam,2007). Asuhan keperawatan merupakan inti pelayanan/praktik keperawatan (Ali,2002).

\section{TUJUAN DAN MANFAAT PROSES KEPERAWATAN}


Tujuan menetapkan proses keperawatan adalah untuk menghasilkan asuhan keperawatan yang berkualitas (Hidayat,2008). Tujuan penerapan proses keperawatan bagi pasien adalah untuk mempertahankan kesehatan klien, mencegah sakit yang lebih parah/komplikasi akibat penyakit, membantu pemulihan kondisi pasien, dan mengembalikan fungsi maksimal tubuh, serta membantu klien terminal meninggal dengan tenang.

\section{TEORI YANG MENDASARI PROSES KEPERAWATAN}

a. Teori sistem, yaitu suatu kerangka kerja yang berhubungan dengan aspek social, manusia, struktur, masalah-masalah organisasi, serta perubahan hubungan internal dan lingkungan disekitar. Keterkaitan teori sistem dengan proses keperawatan dapat dijelaskan melalui masukan (input), hasil (output) dan umpan balik (feedback) (Nursalam,2008).

b. Teori kebutuhan manusia, setiap kebutuhan manusia adalah suatu ketegangan internal sebagai akbibat dari perubahan setiap komponen sistem. Tegangan tersebut dimanifestasikan dalam perilaku untuk memenuhi kebutuhan atau tujuan sapai tingkat kepuasan klien (Nursalam,2008).

c. Teori persepsi, perubahan dalam pemenuhan kebutuhan dasar manusia sangat dipengaruhi oleh persepsi individu. Akibatnya, setiap perubahan terjadim persepsinya antara individu satu dengan yang lain selalu berbeda (Nursalam,2008).

d. Teori informasi dan komunikasi, perawat dituntut mempunyai pengetahuan tentang konsep dan teori sebagai dasar dalam mengartikan data yang diperoleh serta menjalin komunikasi yang efektif (Nursalam,2008).

e. Teori pengambilan keputusan dan penyelesaian masalah, setiap pengambilan keputusan dan penyelesaian masalah menuntut untuk dapat menerima hal baru, perbedaan, aspekaspek yang lebih kompleks dari lingkungan yang ada (Nursalam,2008).

\section{METODE ASUHAN KEPERAWATAN}

Empat metode pemberian asuhan keperawatan professional menurut Kron. T \& Gray (1997).

a. Model asuhan keperawatan professional fungsional, model ini berdasarkan orientasi tugas dan filosofi keperawatan, perawat melaksanakan tugas tertentu berdasarkan jadwal kegiatan yang ada (Nursalam,2002) 
b. Mode asuhan keperawatan professional kasus, metode penugasan kasus biasanyan diterapkan dengan satu pasien satu prawat. Hal ini umumnya dilaksanakan untuk perawat privat atau keperawatan khusus seperti isolasi, intensive care. Metode ini berdasarkan pendekatan holistic dari filosofi keperawatan. Perawat betanggung jawab atas asuhan dan observasi pada pasien tertentu (Nursalam, 2002).

c. Model asuhan keperawatan professional primer, metode keperawatan prier terdapat kontinutas keperawatan yang bersifat komprehensif serta dapat dipertanggung jawabkan. Perawat primer biasa memiliki pasien 4-6 orang dan bertanggung jawab selama 24 jam.

d. Model asuhan keperawatan professional tim, model tim didasarkan keyakinan bahwa setiap anggota kelompok mempunyai kontribusi dalam merencanakan dan memberikan asuhan keperawatan sehingga timbul motivasi dan rasa tanggung jawab perawat yang tinggi sehingga diharapkan mutu assuhan keperawatan meningkat.

\section{KOMPONEN PROSES KEPERAWATAN}

\section{Pengkajian}

Pengkasian meliputi proses pengumpulan data, memvalidasi, dan menginterpretasikan informasi tentang pasien sebagai individu yang unik. Pengkajian harus dilakukan secara komprehensif terkait dengan aspek biologis, psikologis, social maupun spiritual klien. Tujuannya adalah untuk mengumpulkan informasi dan membuat data dasar klien. Metode yang dapat digunakan dalam pengumpulan data adalah wawancara, observasi dan pemeriksaan fisik serta diagnostik (Asmadi,2008).

2. Diagnosa keperawatan Yaitu tahap pengambilan keputusan professional dengan menganalisis data yang telah dikumpulkan. Pernyataan diagnosis keperawatan harus jelas, singkat, dan lugas terkait masalah kesehatan klien, selanjutnya penyebabnya yang dapat diatasi melalui tindakan keperawatan (Asmadi,2008). Manfaat diagnose keperawatan adalah sebagai pedoman dalam pemberian asuhan keperawatan karena menggambarkan status kesehatan (Gaffar,1999).

\section{Perencanaan}

Intervensi atau tahap perencanaan melibatkan serangkaian tahap dimana perawat dan pasien menyusun prioritas, menulis tujuan dan hasil yang diharapkan. Kemudian menulis 
rencana tindakan guna menyelesaikan masalah klien. Jenis rencana keperawatan meliputi intervensi mandiri, intervensi kerjasama (interdependensi) dan intervensi tergantung. Intervensi Mandiri melibatkan aspek-aspek praktek keperawatan profesional yang secara hukum dilakukan perawat dan tidak membutuhkan supervisi atau arahan dari profesi lain. Intervensi interdependensi dilakukan oleh perawat dengan kolaborasi dengan tenaga kesehatan lain.

Intervensi tergantung berdasarkan pada instruksi atau pesan tertulis dari profesi lain

\section{Implementasi}

Perawat mengarahkan, menolong, mengobservasi dan mendidik semua personil keperawatan dan pasien, termasuk evaluasi perilaku dan pendidikan, merupakan supervisi keperawatan yang penting. Implementasi dari rencana keperawatan harus mengikuti komponen perencanaan dari proses keperawatan. Perawat professional harus menggunakan semua teknik manajemen, yang salah satunya adalah supervisi. Untuk membantu staf memberikan asuhan keperawatan dengan baik, perawat harus mampu menggunakan sikap kepemimpinan yang meyakinkan bahwa pasien benar-benar menerima asuhan yang diperlukan setiap waktu dan dengan cara seperti yang diinginkan.

\section{Evaluasi}

Evaluasi adalah tahap akhir dari proses keperawatan yang merupakan perbandingan sistematis dan terencana antara hasil akhir yang teramati dan tujuan atau kriteria hasil yang dibuat pada tahap perencanaan. Evaluasi dilakukan secara bekesinambungan dengan melibatkan klien dan tenaga kesehtan lainnya. Secara umum ealuasi ditujukan untuk : melihat dan menilai kemampuan klien dalam mencapai tujuan ; menentukan apakah tujuan keperawatan telah tercapai atau belum ; mengkaji penyebab jika tujuan asuhan keperawatan belum tercapai (Asmadi,2008)

Mutu pelayanan keperawatan sangat mempengaruhi kualitas pelayanan kesehatan bahkan menjadi salah satu faktor penentu citra institusi pelayanan kesehatan seperti rumah sakit. Hal ini dapat terjadi karena keperawatan merupakan kelompok profesi dengan jumlah terbanyak, paling depan dan terdekat dengan penderitaan orang lain kesakitan, kesengsaraan yang dialami masyarakat. Salah satu indikator dari mutu pelayanan keperawatan yaitu apakah pelayanan keperawatan yang diberikan memuaskan pasien atau tidak (Nursalam, 2011) 
Peran manajer keperawatan dalam mengelola pekerja ataupun sumber lain adalah faktor penting untuk menghasilkan layanan keperawatan yang pofesional dan berkualitas. Sebagai seorang pemimpin memegang peran penting dalam memobilisasi, memantau dan mengarahkan staf untuk meningkatkan kinerja perawat.

Menurut Royal College of Nursing (RCN) (2007), produktivitas harus dimulai dengan kualitas perawatan pasien, penyakit, nilai dan mewakili peningkatan kesehatan pasien. Produktivitas dalam keperawatan bersifat kompleks, penting bagi perawat manajer untuk memahami tentang produktivitas karena akan berdampak pada perawatan pasien dan satu dari sepuluh indikator dalam pemberian asuhan keperawatan (Zoschack,2010).

Mengukur produktivitas kerja perawat merupakan masukan bagi mutu pelayanan keperawatan. Input, proses dan hasil ukur adalah umpan balik yang memungkinkan manajer mengambil keputusan untuk meningkatkan produktivitas perawat dan memberikan pelayanan yang terbaik bagi pasien (North \& Hughes, 2012).

Fako dan Forcheh (2007), menyatakan salah satu faktor yang mempengaruhi produktivitas kerja perawat adalah pelatihan, partisipasi dalam pengambilan kebijakan, kehadiran, pembelajaran dari atasan. Berdasarkan hasil penelitian produktivitas kerja yang tinggi tersebut dapat dipengaruhi oleh kepala ruangan. Kepala ruangan telah memberikan pembelajaran dalam pemberian asuhan keperawatan kepada perawat pelaksana. Kepala ruangan dalam mengatsi konflik telah melibatkan perawat pelaksana dengan terlebih dahulu kepala ruangan mencari informasi. Pembelajaran dalam pemberian asuhan keperawatan berdasarkan standar oprasional dilakukan oleh kepala ruangan.

Bergen \& Severinsson (2012), supervisior juga harus mampu memberi penilaian terhadap hasil kerja perawat pelaksana dalam memberi asuhan keperawatan dalam waktu tertentu. Kualitas pelaksanaan supervisi mendorong untuk meningkatkan kualitas pelayanan keperawatan.

Hasil penelitian yang dilakukan oleh Huton dan Gates (2008), menyatakan bahwa kepuasan dengan supervisor berhubungan positif dengan produktivitas kerja. Menurut Wegman dan McGee dalam Ledvak dan Buck (2008), perawat yang kurang terlatih adalah masalah yang signifikan yang mempengaruhi produktivitas kerja. Untuk mengatasi hal ini, manajer atau kepala ruangan ataupun supervisor diharapkan mampu melaksanakan perannya sebagai perencana, 
pelatih, pemgarah dan pengevaluasi serta sebagai role model yang dapat dilakukan pada saat pelaksanaan supervisi.

Hal ini dibuktikan dengan penelitian dari (Pantintingan, Pasinringi, \& Anggraeni, n.d.) Gambaran Motivasi Kerja Perawat di Ruang Rawat Inap Rumah Sakit Universitas Hasanuddin Makasar. Diperoleh data bahwa motivasi kerja perawat rawat inap Rumah Sakit Unhas, terkait dengan supervisi memiliki presentase $(83.1 \%)$. Penelitian tersebut menunjukkan bahwa dengan diadakannya supervisi pimpinan maka perawat termotivasi untuk meningkatkan kinerja mereka.

Begitu juga dengan hasil penelitian dengan uji Person Product Moment diketahui ada hubungan tinggi antara fungsi supervisi kepala ruangan dengan produktivitas kerja perawat pelaksana di Rumah Sakit Umum dr. Pirngadi Medan. Berdasarkan hasil korelasi tersebut diketahui bahwa fungsi superfisi kepala ruangan berhubungan positif dengan kinerja atau produktivitas kerja perawat pelaksana. Hasil yang diperoleh fungsi supervisi kepala ruangan telah dilaksanakan dengan baik. Produktivitas kerja perawat pelaksanapun diketahui mendekati nilai maksimal. Penelitian ini menunjukan bahwa apabila fungsi supervisi dilaksanakan dengan baik maka produktivitas kerja perawat pelaksana pun juga akan baik.

Hasil penelitian Frimpong, Helleringer, Williams, Yeji dan Phillips (2011), diketahui bahwa kegiatan supervisi dapat meningkatkan produktivitas kerja perawat. Supervisees (penerima supervisi) yang mendapat dukungan dari supervisor ( pelaksana supervisi) menunjukkan bahwa produktivitas kerjanya lebih tinggi dari pada yang tidak mendapat dukungan dari supervisor. Hal ini sejalan dengan yang dikemukan oleh DHHS (2009), bahwa fungsi supervisor (kepala ruangan) adalah memberikan dukungan terhadap masalah yang dihadapi perawat pelaksana dalam pemberian asuhan keperawatan. Berdasarkan hasil penelitian menunjukkan produktivitas kerja perawat pelaksana mendekati nilai maksimal. Hal ini dipengaruhi oleh pelaksanaan supervisi yang telah dilaksanakan dengan baik. Fungsi formatif, restorative, dan normatif secara keseluruhan mendekati nilai maksimal. Oleh karena itu, hasil tersebut mempengaruhi produktivitas kerja perawat pelaksana yang meliputi efektifitas dan efisiensi diketahui rata-rata mendekati maksimal.

\section{PENUTUP}

KESIMPULAN 
Rumah Sakit sebagai salah satu unit tempat pelayanan kesehatan bertanggung jawab dalam memberikan pelayanan yang bermutu, sesuai dengan standar untuk memenuhi kebutuhan dan tuntutan masyarakat.Tenaga profesional kesehatan dalam rumah sakit termasuk didalamnya tenaga keperawatan dituntut untuk memberikan pelayanan kesehatan yang berkualitas.

Pemberian layanan kesehatan yang maksimal dapat dipengaruhi oleh fungsi manajemen kepala ruangan, salah satunya adalah fungsi pengarahan, karena fungsi pengarahan merupakan suatu proses penerapan perencanaan manajemen untuk mencapai suatu tujuan perawatan.

Dari beberapa jurnal yang didapat dapat disimpulkan bahwa terdapat hubungan yang bermakna antara supervisi kepala ruangan dengan kinerja atau produktivitas kerja dari perawat pelaksana, yang memiliki hubungan yang baik atau positif dalam memberikan asuhan keperawatan kepada pasiendan produktivitas kerja perawat pelaksana mendekati nilai maksimal.

Kegiatan supervisi yang tidak dilakukan dengan baik akan memberikan dampak bagi kinerja perawat pelaksana, juga terjadinya pemberian layanan kesehatan yang menurun atau tidak maksimal, sehingga dapat muncul kecenderungan akan adanya kejadian yang tidak diharapkan yaitu nyaris cedera yang bertentangan dengan pasien safety. Seperti pada penelitian Nainggolan (2010) bahwa mutu pelayanan kesehatan dipengaruhi oleh peningkatan atau penurunan kinerja perawat.

Hal tersebut dapat dibuktikan dari beberapa jurnal penelitian yang telah dibahas diatas, didapat bahwa pengarahan yang baik yang dilakukan supervisor dapat menciptakan kerjasama yang efektif dan efisien antara staf.Pengarahan juga berfungsi untuk mengembangkan kemampuan dan keterampilan staf, menimbulkan rasa memiliki dan menyukai pekerjaan, mengusahakan lingkungan kerja yang dapat meningkatkan motivasi dan prestasi kerja, sehingga menjamin keselamatan pasien dan juga perawat.

\section{DAFTAR PUSTAKA}

1. Anggeria,Elis., Maria.2018. Hubungan Supervisi dengan Pelaksanaan Asuhan Keperawatan di Ruang Rawat Inap Lantai 10 Rumah Sakit Umum Royal Prima Medan Tahun 2017.Jurnal Jumantik Vol 3 (2) 
2. Dermawan,D.2012.Proses Keperawatan Penerapan Konsep \& Kerangka Kerja (1sr ed.).Yogyakarta:Gosyen Publishing.

3. Fitrirachmawati.2017. Hubungan Fungsi Supervisi dengan Kepatuhan Perawat Menjalankan SOPIdentifikasi Pasien di RSUP Dr Mohammad Hoesin Palembang Tahun 2015.Jurnal Administrasi Rumah Sakit Indonesia Vol 3 (2)

4. Ginting, Magdalena.,Junita Romaito Sinaga.2019. Hubungan Pelaksanaan Supervisi Kepala Ruang dengan Pendokumentasian Asuhan Keperawatan di Rumah Sakit Martha Friska Pulo Brayan.Jurnal Darma Agung Husada Vol V(1)

5. Hariyati,R.T.S.2014.Perencanaan,Pengembangan dan Utilisasi Tenaga Keperawatan.Jakarta :Rajawali Pers.

6. Harmatiwi, Dini Desi., Sri Sumaryani.,Elsye Maria Rosa.2017. Evaluasi Pelaksanaan Supervisi Keperawatan di Rumah Sakit Umum Daerah Panembahan Senopati Bantul.Jurnal Medicoeticolegal dan Manajemen Rumah Sakit Vol 6 (1)

7. Hidayah,Nur.2014. Manajemen Model Asuhan Keperawatan Profesional (MAKP)Tim dalam Peningkatan Kepuasan Pasien di Rumah Sakit.Jurnal Kesehatan Vol VII (2)

8. Megawati, Sri Wulan., Andria Pragholapati.2020. Supervisi Keperawatan di Rumah Sakit.Jurnal Keperawatan'AisyiyahVol 7 (1)

9. Mugianti,Sri.2016. Modul Bahan Ajar Cetak Keperawatan : Manajemen dan Kepemimpinan dalam Praktek Keperawatan.Kebayoran Baru Jakarta Selatan.

10. Nursalam.2015.Manajemen Keperawatan: Aplikasi dalam Praktik Keperawatan Profesional, Edisi 5. Jakarta : Salemba Medika.

11. Rohmatulloh., Ani Haryani.2018. Hubungan Supervisi Keperawatan dengan Perilaku Caring Perawat dalam Merawat Pasien Kritis.Helath Journal Vol 5 (3)

12. Sihotang, Havija., Heru Santosa., Salbiah.2016. Hubungan Fungsi Supervisi Kepala Ruangan Dengan Produktivitas Kerja Perawat Pelaksana di Rumah Sakit Umum Daerah dr PirngadiMedan.Idea Nursing JournalVol VII (1)

13. Simamora,R.H.2012.Buku Ajar Manajemen Keperawatan.Jakarta:EGC.

14. Simamora, R.H.2019.Development of Guidelines for Applying Approprite Patient Identification to Achieve Patient Safety Goal INC2019 12th International Nursing 
Conference.2019.10 455-455 (1 pages) UCI(KEPA) : 1410-ECN-0101-2019-512001224337

15. Simamora,R.H.2008. The Correlation of Ward Chief's Giving Direction and Command and the Perfomance of On-Duty Nurses at Jember dr. Subandi General Hospital Inpatient Wards.Jurnal Administrasi dan Kebijakan Kesehatan,(https://fkm.unair.ac.id/jurnal-administr)

16. Yanti, Ida Retyaningsih., Bambang Edi Warsito. 2013.Hubungan Karakteristik Perawat Motivasi dan Supervisi dengan Kualitas Dokumentasi Proses Asuhan Keperawatan.JurnalManagemen KeperawatanVol 1 (2)

17. Zendrato, Meylona Verawaty., Rr.Tutik Sri Hariyanti.2017. Optimalisasi Pengelolaan Asuhan Keperawatan di Instalasi Rawat Jalan Rumah Sakit X.JPPNI Vol 2 (2)

18. Zulkarnain.2017. Analisis Pelaksanaan Fungsi Manajemen Pengarahan kepala Ruangan dengan Kinerja Perawat dalam Menerapkan Asuhan Keperawatan di Ruang Rawat Inap RSUD Bima.Jurnal Ilmu Sosial dan Pendidikan Vol 1 (2) 